\title{
PLANT PHYSIOLOGY IN CZECHOSLOVAKIA
}

\author{
By Prof. WALTER STILES, F.R.S.
}

$\mathrm{A}^{\mathrm{T}}$ $\mathbf{T}$ the invitation, and as the guest, of the Czechoslovak Academy of Sciences, I recently had the opportunity of visiting a number of plant physiological research establishments in Czechoslovakia. Since, so far as I know, few if any British plant physiologists have visited these institutions during the past twenty years, a brief impression of them may be of interest to Western readers.

In Prague, plant physiological research is carried out in two institutions, the Charles University and the Biological Institute of the Academy of Sciences. As most readers will know, the Charles University is one of the oldest in Europe, having been founded in the year 1348. For a time, in the latter part of the nineteenth and first part of the twentieth centuries, there were two universities in Prague, a Czech and a German, but since the War no such division of university administration any longer exists. The plant physiological department of the University, under the direction of Prof. S. Prát, is housed in the buildings of what was formerly the German University, which will be associated in the minds of older botanists with such well-known names as Molisch and Czapek. It is perhaps less well known that Sachs, who with reason has been regarded as the founder of modern plant physiology, worked for a time in Prague. These buildings are now sixty years old, but are spacious and well equipped, and the fine library with its large collection of pamphlets happily survived the German occupation although, unfortunately, the index of these was destroyed. Here much research is in progress under Prof. Prát's direction, as is indicated by the considerable body of publications which have appeared from his department during the past twelve years. Of work being carried out at present, particular attention is being given to the absorption of humic substances and their influence on plant metabolic processes. As botanists in Britain will know, a large collection of pure cultures of algae was made in Prague by Prof. E. G. Pringsheim and a collection of them was instituted in Cambridge during his residence there. Although many of his original cultures were lost to Prague after his departure from that city, others have been added and there is now maintained in the plant physiological department of the Charles University a large collection of cultures, not only of algae, including Cyanophyceae, but also of liverworts and mosses.

In the chair at the Charles University, Prof. Prát succeeded Prof. B. Němec, whose plant physiological researches in many fields won him a world-wide reputation half a century ago. It was a particular pleasure to me again to meet Prof. Nëmec and to be able to report to the many admirers of his work that in his eighty-sixth year he is hale and hearty and alert. To commemorate his eighty-fifth birthday in March 1958 a memorial volume entitled "Studies in Plant Physiology" was produced by the Czechoslovak Academy of Sciences and in which twenty-four distinguished botanists from many countries, including the United States, France, Holland, West Germany and Yugoslavia, as well as Central and Eastern European countries, contributed.
It is interesting to note that among those paying tribute to Prof. Nermec in this way was another veteran plant physiologist, Prof. W. J. V. Osterhout.

The Institute of Biology of the Czechoslovak Academy of Sciences has been so called since 1952, when the Academy was constituted; actually the building dates from 1926, having originally been devoted to research in agronomy and phytopathology. During 1950-52 it housed the Central Institute of Biology and Central Institute of Chemistry. The Institute is under the direct auspices of the Academy and is a purely research institution under the direction of Dr. I. Málek. Not only plant physiology but other experimental aspects of biology are dealt with here; these include microbiology, phytopathology, parasitology, radiobiology and electron microscopy among others. About a hundred research workers are engaged in investigations in the Institute. Among research projects of interest to plant physiologists are investigations on the relations between osmotic value and water deficit, cytochemical researches on mitochondria and their relation to plastids, and bud development in relation to the season of maturity and biennial bearing. Although the present buildings impress one as modern and very well equipped, new buildings for the purpose of biological research are being built.

In Brno, plant physiological work is in progress in two institutions, the laboratory for plant physiology and anatomy of the University and the Botanical Institute of the Technical University. In the former, under the direction of Prof. V. Rypáček, several researches of interest to plant physiologists are in progress. Among these may be mentioned the investigation of the growth and action of a number of wood-destroying fungi, including their effect on the composition of the attacked wood, the action of humic acid on the growth of plants, and the effect of one plant on another, with particular reference to the influence of couch grass on wheat, an effect which appears to be very striking. In the Technical University, Prof. R. Dostál, whose first work on correlation was published fifty years ago, many years before the word auxin had even been thought of, is still working enthusiastically on problems of correlation. Here, in the city where Mendel lived and worked, I was pleased to visit the little monastery garden where he carried out his pioneer experiments. In the garden is a stone with an inscription in Czech, German and French recording the fact that here Mendel carried out his experiments.

In Bratislava, the capital of Slovakia, scientific interests are in the care of the Slovak Academy of Sciences, while at the Comenius University plant physiology is in the charge of Prof. L. Pastýrik. The plant physiological laboratory here dates from 1936, and it is interesting to note that it was at first under the direction of Prof. B. Němec. Here a main plant physiological interest is in the mineral nutrition of plants. Thus, work has recently been published on the movement and accumulation of mineral nutrients in the xylem and phloem of apple and pear trees and on the dependence of the metabolism of tobacco leaves on micro-nutrients. 
The site has been cleared in Bratislava for a new institute which will house plant physiology. If this is equal in quality to the fine Institute of Biochemistry maintained by the Slovak Academy of Sciences, plant physiology will be well provided for in the capital of Slovakia.

The time at my disposal did not permit me to visit Košice in the south-east of Slovakia ; but I was given to understand that work of high quality on photosynthesis was in progress there.

Archæology, although outside my range of special knowledge, is within my field of general interests, and I was therefore pleased to visit the Archrological Institute of the Slovak Academy of Sciences at Nitra. This is appropriately housed in Nitra Castle and is provided with a fine library and laboratories well equipped on modern lines.

I cannot conclude this brief account of my impressions of plant physiological activities in Czechoslovakia without expressing my indebtedness to the Czechoslovak Academy of Sciences and the Slovalk Academy of Sciences for the excellent arrangements made for my visits to the various research institutions and of my deep appreciation of the friendliness and kindness I experienced from everyone I met in Czechoslovakia and particularly from my plant physiological colleagues in Prague, Brno and Bratislava and from the director and staff of the Archæological Institute in Nitra.

\section{SELF-REGULATION IN LIVING SYSTEMS}

\section{SYMPOSIUM AT OTTAWA}

\begin{abstract}
A SHORT symposium on self-regulation in living systems, organized by Dr. D. K. C. MacDonald, was held at the laboratories of the National Research Council in Ottawa on October 20. About twenty-five representatives of a wide range of professionsbiophysics, electrical engineering, mathematics, neurology, philosophy, physies, psychology and zoologytook part in the symposium and an attempt was made to establish some common ground within these fields through problems of interest to all. This first meeting was necessarily of an exploratory nature.

The problem of self-regulation in living systems may be considered on two levels. First, the details of self-regulation within a given animal (homeostasis) and its perception of and reaction to the external world, both of these tasks being handled by the nervous system. This might be termed the microscopic picture. Second, there is the relation of animal populations with their surroundings (ecology)-or the macroscopic level. In both cases the processes involved are analogous to those found in the inanimate control systems of physies and engineering.

Papers outlining our knowledge of the nervous system were read by Dr. B. Delisle Burns and Dr. P. M. Milner, both of McGill University, and by Dr. E. A. Atack (Ottawa). A nerve cell, or neurone, when stimulated sufficiently, will transmit the signal to other neurones which are connected to it. This period of activity is followed by a refractory period, or 'dead-time', and thus the mode of action is analog. ous to a Geiger counter tube. In the control centres of an animal the neurones appear to be connected together in an unorganized fashion (a useful genetic property) to form a 'nerve net'. A mathematical treatment of the propagation of signals within such nets has been given by Beurle (1956). Nerve nets in the lower control centres are responsible for selfsustaining processes within the body. For example, the control of respiration is due to nets located within the brain stem. The processes of learning and memory appear to be associated with the nerve nets located in the cerebral cortex or outer layer of the brain. It is supposed that repeated applications of the same stimulus produce some change in the neurones affected by it (or in their connexions), and thus pathways within the nets become established. Similarly, an association of pathways may be built up. Thus memory seems to be due to combinations of
\end{abstract}

neurones. Since, in man, there are about $10^{10}$ neurones involved the total possibilities are obviously enormous - in marked contrast to insects (where the relevant number is of the order $10^{2}$ ) which neverthe. less show an apparently complex behaviour. Cerebral malfunctioning may affect the internal workings of the body or show external effects. Thus analysis of pathological symptoms will suggest the site of a particular disturbance.

A particular aspect of the nervous system, the handling of visual information, can be readily demonstrated. Dr. A. Burton (University of Western Ontario) presented some rather sophisticated optical illusions exhibiting: (1) a biochemical cycle in the retina, (2) adaptation in the cerebral cortex, and (3) the subjective nature of much visual information.

There was, inevitably, a discussion on the relation of computing machines to the brain, initiated by Dr. D. K. C. MacDonald (National Research Council). The ability of present-day computors to make decisions involving some long-term strategy was emphasized. It was suggested in the discussion that a dis. tinction between an animal and a machine could be made in terms of the responses of an animal at 'higher' levels (for example, pleasure, pain) and by the fact that an animal does not always appear to behave logically.

Some large-scale aspects of self-regulation were summarized by Dr. Max Dunbar (McGill University). Particular ecological systems wero discussed and it was concluded that a non-oscillatory state provides optimum conditions for survival. (Indeed, violent oscillations may prove lethal to a particular species.) Some animals contribute to stable conditions by relatively inefficient breeding habits and by tendencies or conditions leading to a high death-rate. Relations between population-lovels of various species are often analogous to feedback system characteristics. It seems, therefore, that ecological systems may show an apparent ability to 'learn'. Of interest here is J. Z. Young's description of the brain as an ecology of nerve cells.

The freely ranging discussion provoked by all the papers indicated that the gaps between the various dis. ciplines had certainly been narrowed. It is hoped that a further symposium on a similar topic will be organized in the near future. An informal report of this symposium is in preparation. Douglas L. MARTIN 